\title{
The Effect of Temperature on the Growth of Bacterium coli at pH 7.0 with a Constant Food Supply
}

\author{
By R. C. JORDAN AND S. E. JACOBS \\ From the Physiology Institute, University College of South Wales and Monmouthshire, \\ Cardiff, and the Bacteriological Laboratory, Imperial College \\ of Science and Technology, London
}

SUMMARY: The effect of temperature on the growth of Bact. coli under accurately controlled conditions has been examined in an apparatus which permits food to be supplied at any desired rate by means of an automatic syringe mechanism. Six temperatures were used, from $15^{\circ}$ to $40^{\circ}$ at $5^{\circ}$ intervals, with a single rate of food supply. Total and viable cell counts were frequently made and growth curves constructed. In some cases the changes in numbers were followed after stopping the food supply.

At all stages the total counts greatly exceeded the viable. There was always first an 'initial' phase in which the daily increments in total cells varied with time. Very early in this phase cell division lagged behind cell growth. At $15^{\circ}$ this condition probably persisted throughout the whole experiment. The initial phase was longest when the temperature was lowest, but the time taken to reach $300 \times 10^{6}$ total cells $/ \mathrm{ml}$. did not vary greatly, except at $15^{\circ}$ when the time was markedly increased. The yield of total cells at the end of the initial phase was highest when the temperature was lowest and depended on the amount of food added, i.e. on the duration of the phase, but relatively more cells were formed in a long than in a short phase. The viable cell count at the end of the initial phase was also enhanced by low temperature, except at $15^{\circ}$ where the viable cells were fewer than expected in comparison with the other experiments. The ratio of the total to the viable count at the end of the initial phase was often close to $2 \cdot 0$.

The initial phase was followed by a 'steady' phase in which there were, on the whole, constant daily increments in both total and viable counts, although there were indications of stepwise increments. In the steady phase the calculated rates of increase in both total and viable cells were highest when the temperature was low, and bore a linear relation to the temperature. The rate of increase in viable cells was almost zero at $35^{\circ}$, which was apparently a critical temperature for viability. At $40^{\circ}$ there was only a slow decline in viable cells, but nevertheless at both $35^{\circ}$ and $40^{\circ}$ growth of the cultures occurred since the total counts continually increased, but approximately half the cells formed were non-viable.

To express the difference between the total and viable counts a non-viability index was calculated. This was constant throughout the steady phase and was smallest when the temperature was lowest. The amount of food previously shown to be required for the formation of a new cell at $35^{\circ}$ was found to be not inconsistent with the experimental data at any of the other temperatures, but if this amount were constant the food used per cell for maintenance and wastage must have declined with decreasing temperature.

After cessation of the food supply the total count declined at both $15^{\circ}$ and $30^{\circ}$, being slightly faster at the lower temperature. The viable count also declined during starvation at $15^{\circ}$; the rate of decrease of the viable count was greater at $30^{\circ}$. 
In a previous paper (Jordan \& Jacobs, 1944) an apparatus for the cultivation of bacteria with a constant food supply was described, and the results of preliminary experiments with Bact. coli reported. It was shown that the apparatus would function satisfactorily and continuously for long periods, and that reproducible results could readily be obtained. These preliminary experi-

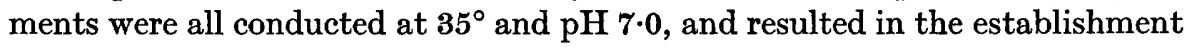
of cultures in which the number of viable cells remained approximately constant while the total cells steadily increased; the numerical values attained depended on the rate of addition of food. The existence of these conditions enabled the calculation to be made of the amount of Difco dehydrated broth required for the formation of a new Bact. coli cell and the maintenance of its full activity apart from reproduction. Further experiments have now been performed with the same organism, apparatus and technique, in order to determine the effect of different temperatures at $\mathrm{pH} 7 \cdot 0$.

\section{APPARATUS AND TECHNIQUE}

Since the apparatus and technique were fully described previously (Jordan \& Jacobs, 1944), full experimental details are not repeated here. A brief summary, however, may be given in order to make the present paper more self-contained. It was desired to study the effect of temperature on the changes in numbers of total and viable cells with time in cultures of Bact. coli which, instead of containing as is usual a large excess of food material, were supplied with food at a regular known rate.

Method of supplying the food. The food addition was effected by means of the automatic syringe mechanism described by Sims \& Jordan (1942) which permits a known volume of sterile nutrient solution to be transferred to the culture at each operation of the syringe. The rate of addition was fixed at $0.066 \mathrm{ml}$. every $100 \mathrm{sec}$. using a solution of Difco dehydrated broth $(6 \mathrm{~g}$./l. before autoclaving), equivalent to an actual addition of $15 \cdot 2 \mathrm{mg}$. of the dehydrated broth $/ \mathrm{hr}$.

The culture flask. This was a $5 \mathrm{l}$. Pyrex round-bottom flask with a central wide neck, around which were arranged three narrower necks. All were fitted with ground sockets, and the connecting fittings were provided with sealed-on glass dust-covers. The central neck served to admit the food solution and an air stream. The other three necks were for the effluent gases, for taking samples for counting purposes and to accommodate a modified dipstick for observing the level of the culture fluid. The final culture volume after autoclaving was $1450 \mathrm{ml}$. The connexions to the food supply were entirely of glass, no rubber being in contact with the food solution. The necessary flexibility in the glass connectors was obtained by spiralling the tubing.

The functions of the air stream. The culture was kept continuously stirred by means of a stream of dry sterile air warmed to the temperature at which the culture was to be grown. This air stream served a number of other purposes. By arranging the apparatus so that the jet through which the food solution entered the culture flask was surrounded by a glass guard tube which also 
served to admit the stream of air, contamination of the entering food by spray from the culture was prevented. The success of the technique largely depended on this.

The air stream further ensured the rapid distribution throughout the whole culture of the food added periodically, and evaporated water from the culture, the rate of flow of air being so adjusted that the water removed just balanced that added in the food solution, thus keeping the culture volume constant. The dipstick referred to above enabled the volume to be checked within $\pm 2 \%$. However, at the lowest temperature investigated $\left(15^{\circ}\right)$ the rate of evaporation was insufficient, with any convenient air flow, to compensate for the food addition; the bacterial counts have therefore been corrected for the small average daily increase in culture volume.

Another essential function of the air stream was to keep the culture adequately oxygenated. The continuous bubbling also prevented the formation of a sediment of cells, the existence of which might have invalidated the cell counts.

Control of $\mathrm{pH}$. Preliminary experiments having shown that in weakly buffered media alkaline metabolic products soon raised the $\mathrm{pH}$ to an inhibitory level, the cultures were buffered at $\mathrm{pH} \mathbf{7 \cdot 0}$ with $\mathrm{M} / \mathbf{3 0}$-phosphate. This sufficed to hold the $\mathrm{pH}$ reasonably constant throughout the longest experiments, which exceeded 30 days. The final $\mathrm{pH}$ was never above $7 \cdot 4$; other work has shown that a change of this magnitude has little effect on the growth of these cultures.

Temperature control. The culture flask was immersed in a thermostatically controlled water-bath up to the unions of the necks with the flask. The temperature variation did not exceed $\pm 0 \cdot 1^{\circ}$.

Procedure at the beginning of an experiment. $1550 \mathrm{ml}$. of the phosphate buffer were placed in the culture flask and the whole autoclaved, the final volume being $1450 \mathrm{ml}$. The stock food solution was autoclaved in a 31 . Pyrex reservoir flask. All connecting parts such as the food jet, level indicator, syringe mechanism, etc., were wrapped separately in paper and sterilized in a 'drying' autoclave. When cool, the culture flask was placed in the waterbath at the desired temperature, the various parts of the apparatus fitted together aseptically, and the air stream started.

After temperature equilibrium had been reached the inoculum was added to the flask and the syringe mechanism controlling the food supply set in operation. Inoculation was at the rate of 300-400 cells $/ \mathrm{ml}$. of buffer; this was achieved by adding $5 \mathrm{ml}$. of a suitable dilution in sterile water of a $24 \mathrm{hr}$. Difco nutrient broth culture of Bact. coli type $I$ grown at $35^{\circ}$. Samples $(2.5 \mathrm{ml}$.) of culture were withdrawn from the culture flask for estimation of the numbers of total and viable cells.

Method of viable counting. The usual plating technique was employed, the culture sample being diluted in sterile $\mathbf{M} / \mathbf{3 0}$-phosphate buffer solution. Eight replicate plates on Difco nutrient agar were made from a suitable dilution of each sample and these were incubated at the temperature of the experiment concerned, except when this was $15^{\circ}$, when an incubation temperature of $20^{\circ}$ was used in order to accelerate growth of the colonies. 
Estimation of total cells. The turbidity of the sample was measured in a Spekker photoelectric absorptiometer and the results converted to numbers of cells by means of a factor established from special calibration experiments. The latter were conducted at $35^{\circ}$ as described above, and the turbidity was determined on samples which were also used for direct microscopic counts. A Thoma counting chamber $0.02 \mathrm{~mm}$. deep was employed, using a $\frac{1}{6}$ in. objective and an $18 \times$ compensating ocular. The organisms were killed and stained to render them more easily visible by the addition of $0.5 \mathrm{ml}$. of $0.1 \%$ aqueous acriflavine to $5 \mathrm{ml}$. of culture. Clumps of cells were very rare and small, and when seen were counted as one unit. Paired cells were infrequent but were counted as one unit unless obviously on the point of separating.

A large number of statistically satisfactory direct counts were obtained, the standard errors of which varied from \pm 2 to $\pm 6 \%$ according to the number of organisms counted (Fisher, 1938). It was then found that the ratios of the numbers of cells $/ \mathrm{ml}$. of the culture to the absorptiometer readings (corrected for the gradually deepening colour of the culture caused by the accumulation of the yellow-brown coloured material of the broth) were scattered about a mean. This had a value of 13.62 million cells/ml./absorptiometer unit, with a standard error of \pm 0.26 million, i.e. approximately $2 \%$. This method is, however, not suitable for estimating extremely low numbers of cells, and total cell counts based on absorptiometer readings of 1 unit or less are therefore only approximate.

\section{EXPERIMENTAL AND RESULTS}

Experiments performed. Experiments were carried out at temperatures of $15^{\circ}, 20^{\circ}, 25^{\circ}, 30^{\circ}, 35^{\circ}$ and $40^{\circ}$, daily estimations being made of the numbers of total and viable cells. Only one experiment was performed at each temperature, except at $35^{\circ}$, where the data given are the mean values from several replicate experiments previously reported (Jordan \& Jacobs, 1944). Each experiment was continued for at least 22 days, a time amply sufficient to reveal the shape of the growth curve. In two instances, namely, the experiments at $15^{\circ}$ and $30^{\circ}$, the food supply was stopped after 17-18 days, but sampling was continued in order that the effects of starvation could be studied. The results obtained are given in Table 1, and the changes in numbers of total and viable cells with time are shown graphically in Figs. 1-3.

\section{General observations}

It is evident that the general course of the experiments at all temperatures was similar to that of those previously conducted at $35^{\circ}$, in that an 'initial phase' of varying growth rate was followed by a 'steady phase' of roughly constant rate of increase in total cell count. But whereas in the steady phase of the experiments at $35^{\circ}$ the viable count remained approximately constant, in the experiments now reported it increased continually and steadily in all cases except at $40^{\circ}$, in which case there was a tendency for it to decline. It is 
convenient in describing the influence of temperature on the cultures to consider the initial and steady phases separately; the description of the effects of starvation is given subsequently.

Table 1. The effect of temperature on the relation between numbers of total cells $(T)$ and viable cells $(\boldsymbol{V})$ in Bact. coli cultures with a constant food supply.

Cultivation at $\mathrm{pH}$ 7.0. Constant rate of food supply: 15.2 mg. dehydrated Difco broth/hr.

Temperature of experiment $\left({ }^{\circ}\right)$

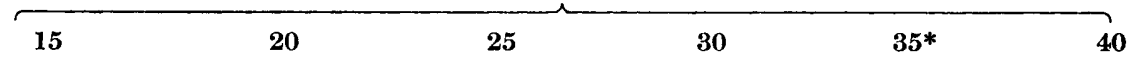

No. of cells (millions/ml.)

\begin{tabular}{|c|c|c|c|c|c|c|c|c|c|c|c|c|}
\hline (days) & $T$ & $\boldsymbol{V}$ & $T$ & $V$ & $\boldsymbol{T}$ & $V$ & $T$ & $\boldsymbol{V}$ & $T$ & $V$ & $T$ & $\vec{V}$ \\
\hline 1 & $\ll 14$ & $<0.0001$ & - & - & 163 & 17 & 164 & $97 \cdot 6$ & 80 & 41 & 204 & 44 \\
\hline 2 & $\ll 14$ & 0.0107 & 315 & 171 & 422 & 130 & 344 & 208 & 218 & 119 & - & - \\
\hline $\mathbf{3}$ & $\ll 14$ & $0 \cdot 638$ & 591 & 320 & 629 & 375 & - & - & 396 & 194 & 409 & 142 \\
\hline 4 & 268 & $37 \cdot 1$ & 825 & 425 & 755 & 506 & 794 & 360 & 514 & 243 & 409 & 174 \\
\hline $\mathbf{5}$ & - & - & - & - & - & - & 842 & 415 & 544 & 259 & 422 & 198 \\
\hline 6 & 1075 & 484 & 1222 & 650 & 1172 & 653 & 903 & 433 & 623 & 281 & 477 & 217 \\
\hline 7 & 1286 & 591 & - & - & 1385 & 680 & 1007 & 467 & 658 & 291 & 463 & 209 \\
\hline 8 & 1725 & 693 & 1396 & 872 & 1450 & 746 & 1120 & 525 & 665 & 301 & 484 & 220 \\
\hline 9 & 1808 & 749 & 1589 & 910 & 1580 & 778 & 1190 & 542 & 649 & 297 & - & - \\
\hline 10 & 1910 & 807 & 1680 & 987 & 1730 & 846 & - & - & 738 & 307 & 477 & 180 \\
\hline 11 & 2142 & 968 & 1880 & 1046 & 1785 & 860 & 1343 & 602 & 800 & 328 & $\mathbf{5 2 5}$ & 186 \\
\hline 12 & 一 & - & - & - & - & - & 1370 & 644 & 804 & 314 & 654 & 178 \\
\hline 13 & 2522 & 1118 & 2100 & 1180 & 2120 & 945 & 1416 & 600 & 856 & 317 & 687 & 181 \\
\hline 14 & 2470 & 1132 & 2240 & 1200 & 2230 & 993 & 1504 & 585 & 879 & 314 & 680 & 156 \\
\hline 15 & 2660 & 1250 & 2360 & 1254 & 2480 & 1088 & 1540 & 664 & 921 & 301 & 627 & 157 \\
\hline 16 & 2782 & 1290 & 2610 & 1320 & 2390 & 1026 & 1566 & 674 & 905 & 284 & - & - \\
\hline 17 & $\dagger 2920$ & $\dagger 1470$ & 2580 & 1400 & 2515 & 1179 & - & - & 993 & 289 & 695 & 136 \\
\hline 18 & 2758 & 1375 & 2630 & 1388 & 2620 & 1157 & $\dagger 1718$ & $\dagger 652$ & 938 & 298 & 722 & 156 \\
\hline 19 & - & - & - & - & - & - & 1650 & 595 & 1010 & 297 & - & - \\
\hline 20 & 2740 & 1345 & 2880 & 1400 & 2810 & 1300 & 1538 & 627 & 1057 & 297 & 830 & 186 \\
\hline 21 & 2670 & 1326 & 2950 & 1515 & 2880 & 1316 & 1668 & 548 & 1119 & 283 & 817 & 197 \\
\hline 22 & 2530 & 1382 & 3100 & 1600 & 2940 & 1340 & 1554 & 558 & 1126 & 277 & 912 & 183 \\
\hline 23 & 2510 & 1274 & - & - & - & - & - & - & 1163 & 282 & - & - \\
\hline 24 & 2550 & 1352 & - & - & - & - & $\ldots$ & - & 1186 & 292 & - & - \\
\hline 25 & 2400 & 1361 & - & - & - & - & 1470 & 540 & 1222 & 270 & - & - \\
\hline 26 & - & - & - & - & - & - & 1445 & 533 & 1254 & 250 & - & - \\
\hline 27 & 2420 & 1320 & - & - & - & - & 1390 & 461 & 1263 & 246 & - & - \\
\hline 28 & $\mathbf{2 4 4 0}$ & - & - & - & - & - & 1380 & 378 & 1255 & 247 & - & - \\
\hline 29 & 2460 & - & - & - & - & - & 1342 & 355 & 1252 & 242 & 一 & - \\
\hline 30 & 2315 & - & - & - & - & - & - & - & 1348 & 246 & - & - \\
\hline 31 & 2280 & - & - & - & - & - & - & - & 1480 & 258 & - & - \\
\hline 32 & - & - & - & - & - & - & - & - & 1535 & 260 & - & - \\
\hline 33 & - & - & - & - & - & - & - & - & 1588 & 255 & - & - \\
\hline
\end{tabular}

* Values given at $35^{\circ}$ are the means from several replicate experiments previously reported (see text).

$\dagger$ The food supply was stopped immediately before these counts.

\section{The initial phase}

During the initial stages of cultivation the growth rates, measured by the increase in either total or viable populations, varied considerably with time, and the graphs of numbers against time are sigmoid (see Figs. 1-3). The end of the initial phase was determined by inspection as the time (to the nearest day) 


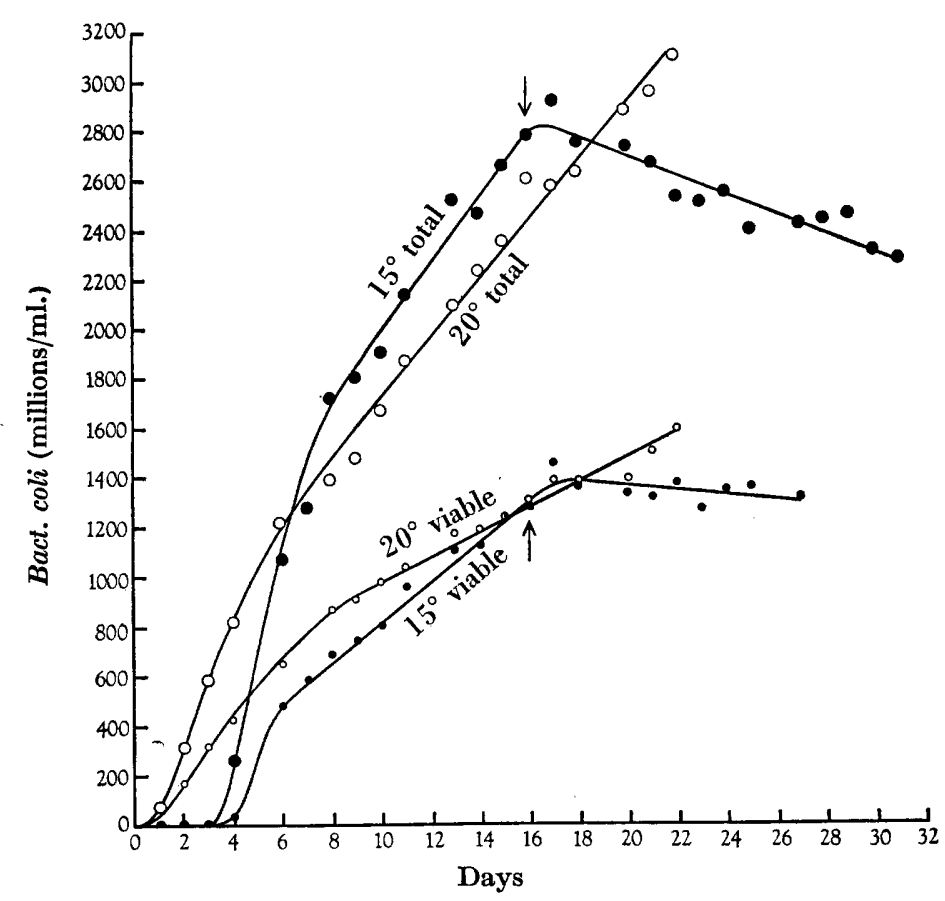

Fig. 1. Growth curves for Bact. coli on a constant food supply of $15 \cdot 2 \mathrm{mg}$. Difeo broth/hr. at $15^{\circ}$ (full circles) and $20^{\circ}$ (open circles) at $\mathrm{pH} \mathrm{7 \cdot 0.} \mathrm{Point} \mathrm{at} \mathrm{which} \mathrm{food} \mathrm{supply} \mathrm{was}$ stopped is marked by arrow.

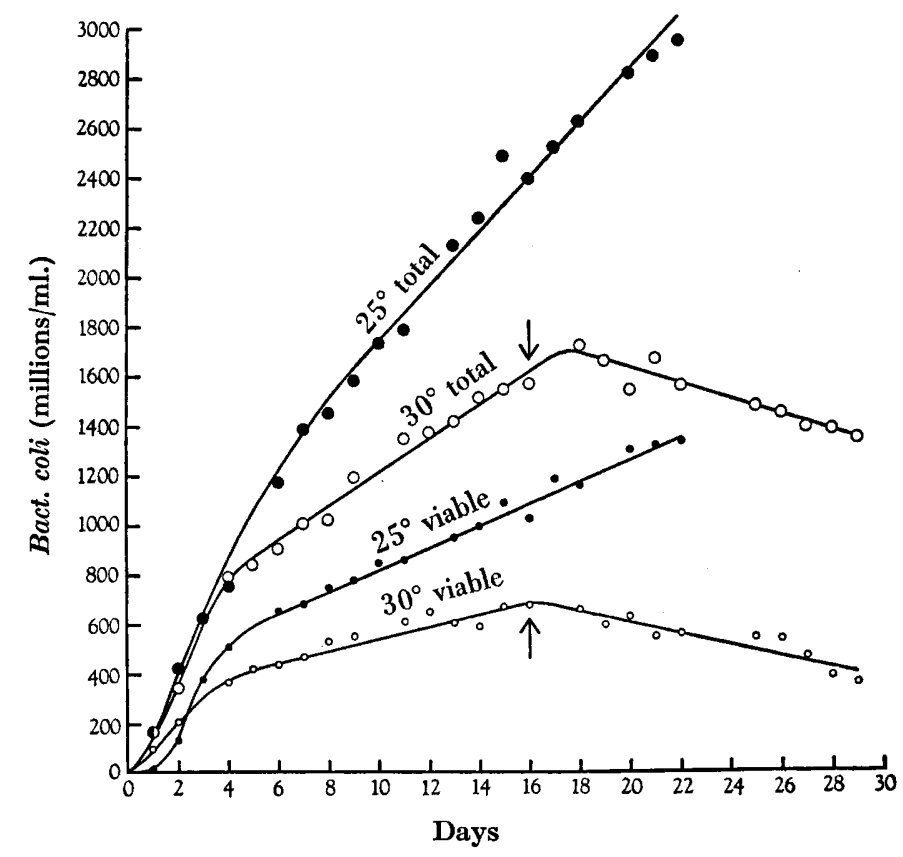

Fig. 2. Growth curves for Bact. coli on a constant food supply of $15 \cdot 2 \mathrm{mg}$. Difco broth/hr. at $\mathbf{2 6}^{\circ}$ (full circles) and $30^{\circ}$ (open circles) at $\mathrm{pH} \mathrm{7 \cdot 0.} \mathrm{Point} \mathrm{at} \mathrm{which} \mathrm{food} \mathrm{supply} \mathrm{was}$ stopped is marked by arrow. 
at which the sigmoid curve of the initial phase met the linear graph characteristic of the steady phase. It was not always easy to fix the exact time, especially when the growth in the early part of the initial phase had been rapid, because the curves then flattened out slowly and the initial phase merged very gradually into the steady phase. However, by plotting the graphs on a large scale and

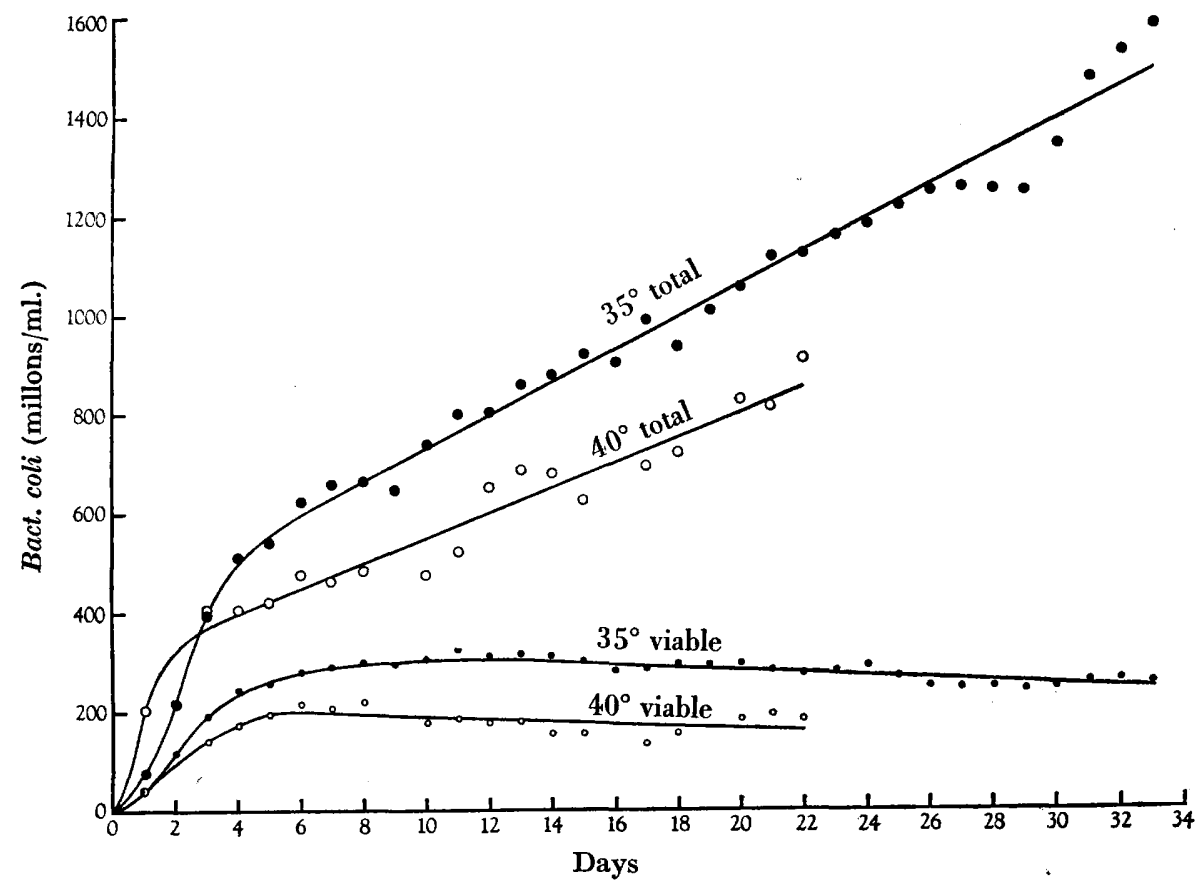

Fig. 3. Growth curves for Bact. coli on a constant food supply of $15 \cdot 2 \mathrm{mg}$. Difco broth/hr. at $35^{\circ}$ (full circles) and $40^{\circ}$ (open circles) at $\mathrm{pH} 7 \cdot 0$.

comparing for each experiment the curves of both total and viable cells, satisfactory times were obtained. The durations of the initial phases are given in Table 2, and it is clear that the length of this phase depended markedly on the temperature, increasing as the latter was lowered.

Table 2. The effect of temperature on the duration of the initial phase, together with the values of the total and viable populations at its termination, i.e. at start of steady phase

\begin{tabular}{|c|c|c|c|c|}
\hline \multirow{2}{*}{$\begin{array}{l}\text { Temp. } \\
\left({ }^{\circ}\right)\end{array}$} & \multirow{2}{*}{$\begin{array}{c}\text { Duration } \\
\text { of initial } \\
\text { phase } \\
\text { (days) }\end{array}$} & \multicolumn{2}{|c|}{$\begin{array}{l}\text { Population at end of initial } \\
\text { phase (millions/ml.) }\end{array}$} & \multirow{2}{*}{$\begin{array}{l}\text { Ratio of total } \\
\text { to viable count } \\
\text { at end of } \\
\text { initial phase }\end{array}$} \\
\hline & & Total $\left(T_{s}\right)$ & Viable $\left(V_{s}\right)$ & \\
\hline 15 & 8 & 1700 & 670 & $2 \cdot 54$ \\
\hline 20 & 8 & 1480 & 880 & $\mathbf{1 \cdot 6 8}$ \\
\hline 25 & 7 & $14: 10$ & 690 & $2 \cdot 04$ \\
\hline 30 & 6 & 945 & 445 & $2 \cdot 12$ \\
\hline 35 & 6 & 595 & 285 & $2 \cdot 09$ \\
\hline 40 & $\mathbf{5}$ & 425 & 205 & $2 \cdot 07$ \\
\hline
\end{tabular}


The effect of temperature on the total cell count at the end of the initial phase $\left(T_{s}\right.$, Table 2$)$ was twofold; there was the anticipated effect of the phase duration, because of the continual addition of food, and also a direct effect of low temperature leading to a further increase in the count. $T_{s}$ is a measure of cell substance, and clearly more was formed relative to the phase length in a long phase than in a short one. Since the initial phase was longest at the lower temperatures, it follows that the efficiency of conversion of food into cell substance was highest at low temperatures. The fact that in general the viable count at the end of the initial phase $\left(V_{s}\right)$ varied in the same way as $T_{s}$ is shown by the relative constancy of their ratios to the total counts (Table 2). These ratios are in several cases very close to $2 \cdot 0$; the mean of the six separate values is $\mathbf{2 \cdot 0 9}$, with a standard deviation of $\pm \mathbf{0 \cdot 2 7 4}$ and a coefficient of variation of

Table 3. The time required to reach a total population of $\mathbf{3 0 0}$ million cells/ml. at various temperatures

$\begin{array}{cc}\begin{array}{c}\text { Temperature } \\ \left({ }^{\circ}\right)\end{array} & \begin{array}{c}\text { Time } \\ \text { (days) }\end{array} \\ 15 & 4 \cdot 2 \\ 20 & 1 \cdot 9 \\ 25 & 1 \cdot 5 \\ 30 & 1 \cdot 7 \\ 35 & 2 \cdot 1 \\ 40 & 1 \cdot 4\end{array}$

$13 \cdot 1 \%$, so it is possible that this ratio should have had a value of $2 \cdot 0$ at all the temperatures employed. However, $V_{s}$ at $15^{\circ}$ was lower than at $20^{\circ}$, after initial phases of equal length; this is anomalous in view of the regular increase in $V_{s}$ with falling temperature between $40^{\circ}$ and $20^{\circ}$.

The behaviour of the cultures in the initial phase varied considerably according to the conditions. Reliable total cell counts below 200 millions $/ \mathbf{m l}$. were secured in only three of the experiments; the shapes of the curves below this point are uncertain. As a basis for comparison of the development of the cultures during the initial phase the time taken to reach a total cell population of $\mathbf{3 0 0}$ millions $/ \mathrm{ml}$. has therefore been arbitrarily chosen. This time falls on the well-defined portions of the curves. It has the additional advantage of corresponding roughly to the cell density in a moderately good broth culture grown for about $18 \mathrm{hr}$. under ordinary conditions, thus affording a means of comparing these cultures with normally grown ones. The times taken to reach 300 million cells $/ \mathrm{ml}$. are given in Table 3 and, as would have been expected, development was slow under these conditions of restricted food supply. Clearly, the effect of temperature was relatively slight until the lowest temperature was reached, when there was a marked slowing in the rate of development to this arbitrary population level. As far as can be seen, the same conclusion would have been reached if a much lower level of population had been chosen. This result is in marked contrast with the influence of temperature on the rate of growth of the cultures in the steady phase (see below). When the viable counts are considered similar effects are seen. 


\section{The steady phase}

As in the experiments previously reported, there was in the subsequent steady phase a tendency for the total counts to increase in a step-wise manner, but at present it is convenient to treat the data as if the rates of cell increase had been constant in each experiment. Also, there was always a marked difference between the total and viable counts, but the major contrast between the present and former (Jordan \& Jacobs, 1944) sets of experiments lies in the fact that at all the temperatures employed except one (at $40^{\circ}$ ) the viable counts instead of remaining approximately constant during the steady phase,

Table 4. The effect of temperature on the relation between numbers of total and viable cells and time in the steady phase

Temp.
$\left({ }^{\circ}\right)$
15
20
25
30
35
40

$$
\begin{array}{ccc}
\begin{array}{c}
\text { Equation of regression of } \\
\text { total count on time }
\end{array} & \begin{array}{c}
\text { Standard } \\
\text { error of } \\
T=T_{s}+\Delta T\left(t-t_{s}\right)^{*}
\end{array} & \begin{array}{c}
\text { Equation of regression of } \\
\text { viable count on time }
\end{array} \\
T=1700+136 \cdot 8(t-8 \cdot 0) & \pm 7 \cdot 01 & V=V_{s}+\Delta V\left(t-t_{s}\right)^{*} \\
1480+118 \cdot 9(t-8 \cdot 0) & \pm 3 \cdot 86 & 880+50 \cdot 6(t-8 \cdot 0) \\
1410+108 \cdot 9(t-7 \cdot 0) & \pm 1 \cdot 17 & 690+44 \cdot 3(t-7 \cdot 0) \\
945+66 \cdot 8(t-6 \cdot 0) & \pm 2 \cdot 41 & 445+24 \cdot 4(t-6 \cdot 0) \\
595+33 \cdot 2(t-6 \cdot 0) & \pm 0 \cdot 90 & 285+4 \cdot 5(t-6 \cdot 0) \\
425+25 \cdot 3(t-5 \cdot 0) & \pm 1 \cdot 82 & 205-2 \cdot 3(t-5 \cdot 0) \\
* T_{s} & =\text { total count in millions/ml. at start of steady phase, } \\
t & =\text { time in days, } \\
t_{s} & =\text { time at which steady phase began, } \\
\Delta T & =\text { rate of increase in total count in millions/ml./day, } \\
V & =\text { viable count in millions/ml. at start of steady phase, } \\
\Delta V & =\text { rate of increase in viable count in millions/ml./day. }
\end{array}
$$

Standard error of

showed a marked and continuous increase. At $40^{\circ}$ the viable counts in this phase showed a slight tendency to decline. Evidently at $\mathrm{pH} 7 \cdot 0$ a temperature of about $35^{\circ}$ is rather critical for the viability of the cells of these cultures.

If these cultures are treated as if during the steady phase there had been regular daily increments in both total and viable counts, it becomes logical to represent these increments by the slopes of the lines of regression of numbers of cells on time. The equations of these lines have been calculated by the usual method of least squares and are given in Table 4 in a form which makes it plain that the lines originate from the points which define the end of the initial phase or, what is the same thing, the beginning of the steady phase (see footnote to Table 4). The straight lines in Figs. 1-3 correspond to these equations. The standard errors of the slopes of these lines are also given; they are seen to be relatively small, but it must be remembered that if the phenomenon of stepwise increments is real these standard errors have little meaning. It may be mentioned that in the steady phase at $35^{\circ}$ the viable counts were only roughly constant (Jordan \& Jacobs, 1944), and a closer approximation to the actual condition is given by a bilinear treatment as shown in Fig. 3. There was first a slow increase followed by a slow decline. The regression equation during this decline has not been given in Table 4 since this line does not pass through the 
point defining the end of the initial phase; the equation therefore cannot be put in the same form as the others in the table. Its equation is $V=351 \cdot 5-3 \cdot 28 t$, and the standard error of the regression coefficient is $\pm 0 \cdot 44$.

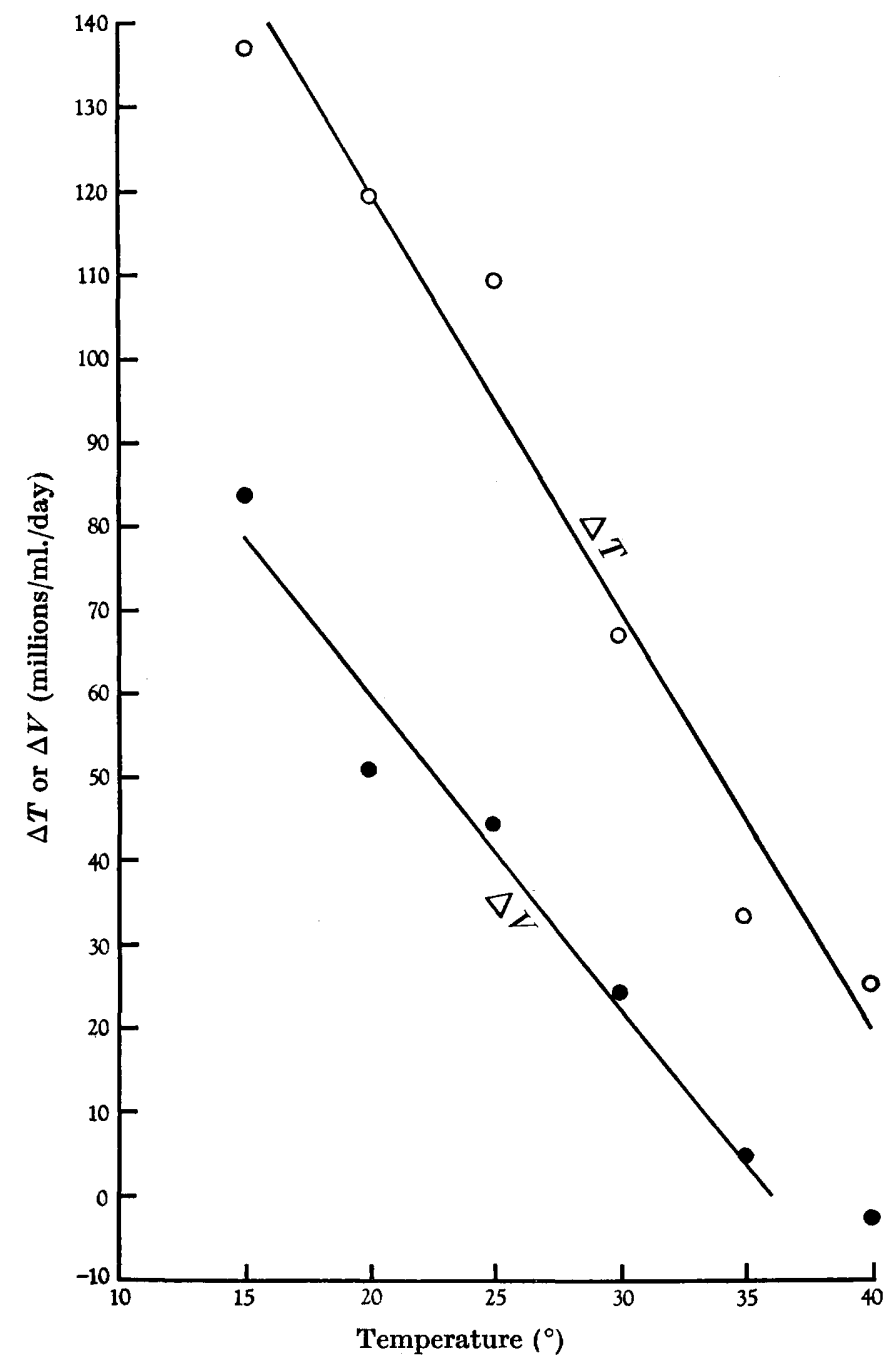

Fig. 4. Relation between daily increment in total cells $(\Delta T)$ and viable cells $(\Delta V)$ and temperature at $\mathrm{pH} \mathbf{7} \cdot \mathbf{0}$.

From Table 4 it is clear that temperature had a marked effect on the rate of formation of viable cells. The striking fact is that the lower the temperature the higher was the rate, and there was an almost exactly linear relationship between temperature and rate of formation between $15^{\circ}$ and $35^{\circ}$. This is shown in Fig. 4, in which the line drawn is the calculated best-fitting straight line whose slope is $-\mathbf{3 \cdot 6 9} \pm \mathbf{0 \cdot 4 1}$. As shown by this graph the rate of increase in the viable count would have become zero at just over $36^{\circ}$ and, if the linear relation- 
ship had continued to hold, a further increase in temperature should have led to a declining viable population. This was actually the case at $40^{\circ}$ (see Table 4), but the rate of decrease was small and much below that anticipated from the linear relationship below $35^{\circ}$.

In these cultures the total cell counts were always much greater than the viable counts. A high rate of increase in the viable count would naturally lead to a high rate of increase in the total count, and this is in fact observed. Although low temperature favoured a high rate of increase in total cells the rate of increase did not reach zero at $40^{\circ}$, where there was a decrease in viable cells. The relationship between temperature and rate of increase in total cells $(\Delta T)$ was linear as shown in Fig. 4, where the line drawn is the calculated bestfitting straight line whose slope is $-4 \cdot 90 \pm 0 \cdot 50$. This line indicates that $\Delta T$

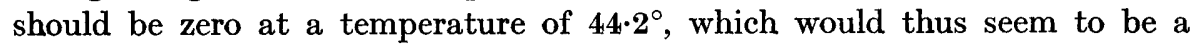
limiting temperature for growth. The best condition for high rate of formation of total cells was, therefore, like that for high rate of formation of viable cells, a low temperature.

\section{The effects of starvation}

Under the conditions of starvation which obtained after the food supply had been stopped, the total and viable counts both fluctuated considerably (Figs. 1, 2). The fluctuations sometimes suggested that step-wise decrements had occurred, but for convenience the changes have been assumed to be linear with time and the slopes of the calculated lines of regression are given in Table 5.

Table 5. The effect of temperature on the daily changes in the total cells $(\Delta T)$ and viable cells $(\Delta V)$ in starved cultures

$\begin{array}{ccc}\text { Temp. } & \Delta T & \Delta V \\ \left.{ }^{\circ}\right) & \text { (millions/ml./day) } & \text { (millions/ml./day) } \\ 15 & -38 \cdot 2 \pm 4 \cdot 37 & -10 \cdot 0 \pm 4 \cdot 96 \\ 30 & -31 \cdot 5 \pm 3 \cdot 56 & -22 \cdot 8 \pm 3 \cdot 45\end{array}$

The total counts declined sharply at both temperatures and more rapidly at the lower, but in the case of the viable cells the higher the temperature the faster was the decline. There was no evidence that the viable counts would have reached a constant low level of about 100 million cells $/ \mathrm{ml}$. as they did in the experiments at $35^{\circ}$ cited above, but the observations were not sufficiently prolonged.

\section{DISCUSSION}

In the cultures studied here so few cells were originally present that the rate of food utilization must at first have been less than that of its addition. The critical food level, at which growth as measured by cell division ceases to be dependent on its concentration (Penfold \& Norris, 1912), may even have been exceeded. Where food concentration does not limit the growth-rate the points obtained by plotting the logarithms of the numbers of viable cells against time should fall on a straight line. At $15^{\circ}$ this was so for a considerable time (Fig. 5), 
but at all other temperatures food was a limiting factor by the first day after inoculation. Since the cells of the inoculum were added to a fluid virtually devoid of nutrients there may have been an inactive period in addition to the usual lag phase in which increase of cell size occurs without cell division. From Fig. 5, by extrapolation backwards according to the method of Lodge \& Hinshelwood (1943), the total lag phase at $15^{\circ}$ is found to have been slightly over 1 day. At all other temperatures it must have been much less. The total lag having been so short, an inactive period could not have constituted an important phase in these cultures. A period of increase in cell size probably

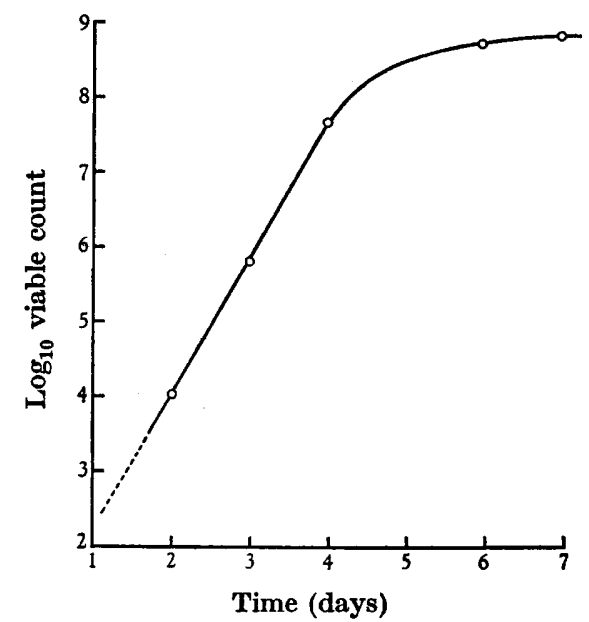

Fig. 5. Relation between log viable count and time in the initial phase at $15^{\circ}$ and $\mathrm{pH} 7 \cdot 0$.

occurred in the early part of the initial phases of the present experiments, since there was an abnormally high ratio of total to viable count at this stage. The ratios calculated for the earliest time in each experiment at which simultaneous. total and viable counts were secured are given in the upper part of Table 6 in order of decreasing magnitude. The ratio yielded by the composite data for $3^{\circ}$ has not been included because, as explained previously (Jordan \& Jacobs, 1944), the counts given at one day (see Table 1) do not reflect the true condition of the individual experiments at that time. In general the lower the viable count the higher is the ratio; not until the former reached 50-100 million cells $/ \mathrm{ml}$. did the latter approach the range of $1 \cdot 68-2 \cdot 54$ characteristic of the end of the initial phase (see Table 2). The individual experiments at $35^{\circ}$ also support this finding. Therefore, unless many cells were non-viable, the individuals must have been abnormally large. A high ratio of total to viable cells persisted longer at $15^{\circ}$ than at any other temperature (see the lower half of Table 6). Further, the viable count at the end of the initial phase at $15^{\circ}$ was unexpectedly low, and these two observations both indicate that at this temperature the so-called normal proportionality between total cells and turbidity may never have been attained. If this were so, the recorded number 
of total cells at the end of the initial phase at $15^{\circ}$ must be larger than the actual number and the ratio $T_{s} / V_{s}$ too high. If the value for $15^{\circ}$ be excluded, the five remaining values of $T_{s} / V_{s}$ in Table 2 have a mean of $2 \cdot 00 \pm 0 \cdot 08$. Apparently, over a wide range of temperature, about half the cells present at the end of the initial phase were incapable of further division. The graphs in Figs. 1-3, purporting to represent changes in total cell numbers with time, ought strictly to be regarded as curves of changes in total cell substance, but it has been found convenient to retain the expression 'numbers of total cells' although it is realized that at $15^{\circ}$ the numbers referred to may be too high.

Table 6. The earliest simultaneous values of the total and viable counts in the initial phase of each experiment, and the total and viable counts at the earliest comparable time in all experiments, with their ratios

$\begin{array}{ccccc}\begin{array}{c}\text { Temp. } \\ \left(^{\circ}\right)\end{array} & \begin{array}{c}\text { Time } \\ \text { (days) }\end{array} & \begin{array}{c}\text { Total count } \\ \text { (millions/ml.) }\end{array} & \begin{array}{c}\text { Ratio of total } \\ \text { (millions/ml. }\end{array} & \begin{array}{c}\text { Ro viable } \\ \text { count }\end{array} \\ 25 & 1 & 163 & 17 & 9 \cdot 6 \\ 15 & 4 & 268 & 37 & 7 \cdot 2 \\ 40 & 1 & 204 & 44 & 3 \cdot 9 \\ 20 & 2 & 315 & 171 & 1 \cdot 8 \\ 30 & 1 & 164 & 98 & 1 \cdot 7 \\ 15 & 4 & 268 & 37 & 7 \cdot 2 \\ 20 & 4 & 825 & 425 & 1 \cdot 9 \\ 25 & 4 & 755 & 506 & 1 \cdot 5 \\ 30 & 4 & 794 & 360 & 2 \cdot 2 \\ 35 & 4 & 514 & 243 & 2 \cdot 1 \\ 40 & 4 & 409 & 174 & 2 \cdot 4\end{array}$

The view has already been put forward (Jordan \& Jacobs, 1944) that at the end of the initial phase the cultures became stabilized in the sense that any food which may have accumulated in the early stages had been used up, so that further additions were consumed as fast as they were supplied, a condition which resulted in the so-called steady phase. Under these conditions the numbers of both total and viable cells appeared to show a distinct tendency to increase in a step-wise manner (see Figs. 1-3). Other workers have recorded that in the logarithmic phase of ordinary cultures growth may proceed in waves (Wilson \& Miles, 1946). At present a convenient and satisfactory approximation is to treat these cultures as if there had been regular daily increments in numbers during this phase. The increments ( $\Delta T$ and $\Delta V$ for the total and viable counts respectively) are measures of the rates of growth of the cultures as a whole and do not reflect the division rates of the individual cells. Evidently, the numbers of total and viable cells formed from a fixed amount of food remained approximately constant irrespective of the age of the culture, i.e. of the number of cells composing it. Bail (1929) suggested that for any given culture and conditions of growth there is a maximum population which can be supported. The experiments reported here are in agreement with this view in so far as the numbers of viable cells are concerned, but only provided that the temperature of incubation is not too far removed from that ordinarily 
considered to be the optimum for the organism employed (in this case $37^{\circ}$ ). If the total amount of cell substance is regarded as the 'population' in these cultures, then there appears to be no indication, at any of the temperatures used, of the existence of Bail's maximum population.

Changes in temperature markedly affected $\Delta T$, which was highest when the temperature was lowest and, as there was a constant food supply, it is evident that the efficiency of conversion of the food into cell substance increased with decreasing temperature. This appears at first sight to be irreconcilable with the usual conception of the optimum temperature for growth. But the latter is normally obtained from cultures growing in the presence of a large excess of food and really represents the temperature at which the mean generation time of the cells is minimal, no account being taken of the efficiency of the process. It is indicated below that, with decreasing temperature, the amount of food wasted by the cells in reactions not leading to synthesis of cell substance declined. With a limited food supply this must have led to an increase in the overall efficiency. The relative amounts of different enzymes in the cells may have varied with the growth temperature (Gale, 1940), and this would have farreaching effects. In the initial phase, however, variation of temperature within wide limits did not affect the rate of development of the cultures to an arbitrary population level, and the two measures of the growth of the cultures are therefore not comparable. As shown above, it can be deduced that $44.2^{\circ}$ is a limiting value above which, in these particular conditions, no growth would have occurred. It is of course true that the type I Bact. coli used in this work will grow rapidly at $44^{\circ}$ in other nutritional conditions; it is Eijkman-positive and grows and forms gas from lactose at that temperature in MacConkey's broth.

The magnitude of $\Delta V$ was also very dependent on the temperature, being greatest when the latter was low. High levels of $\Delta V$ would naturally tend towards large values of $\Delta T$, and, in fact, there was a strong tendency in that direction as can be seen from Table 4. Table 7 , however, shows that $\Delta V$ became larger relative to $\Delta T$ as the temperature decreased. The ratio of $\Delta V$ to $\Delta T$ is a measure of the extent to which the cells formed retained their viability, but it is not the best measure of this property, since it was not true that no growth occurred in the cultures in which $\Delta V$ was zero. A better measure is the non-viability index (n.v.i.) which has been defined (Jordan \& Jacobs, 1944) as the proportion of the cells formed in a generation which is non-viable; this can be calculated in the following manner. The true generation time at any moment in this phase is the time required for a number of viable cells $(V)$ to form $V$ additional cells. Some of these were viable and others not, but they all contributed to the increase in total cells and required for their formation $V / \Delta T$ days. The increase in viable cells was therefore $V \Delta V \mid \Delta T$, and the actual number of viable cells at the end of this time was thus $V(1+\Delta V \mid \Delta T)$. If all the cells formed had been viable, the expected number of viable cells should have been $2 V$, and the value of the n.v.i. is therefore $\frac{1}{2}(1-\Delta V \mid \Delta T)$. These values are given in Table 7 and show that retention of viability was greatest at the lower temperatures, the index increasing sharply above $30^{\circ}$. The value 
at $15^{\circ}$ may in reality have been even lower than appears from Table 7. Since at this temperature the individual cells were apparently larger than normal, the recorded value of $\Delta T$ must be greater than it actually was. Clearly, in this steady phase the food available per cell did not affect the n.v.i., since the latter was constant while the former diminished with time, and the cultures with the densest populations, and therefore the lower food supply per cell, had the lowest indices. Temperature was thus the important factor controlling the n.v.i. In connexion with the favourable effect of the lower temperatures on viability as well as on the rate of formation of cell substance, it may be recalled that Thompson (1942) pointed out that there is a wealth of microbial life in cold seas compared with that found in tropic waters.

Table 7. The effect of temperature on the ratio between the daily increments in viable and total cells $(\Delta V / \Delta T)$, and on the non-viability index (n.v.i.) during the steady phase

$\begin{array}{ccc}\begin{array}{c}\text { Temp. } \\ \left({ }^{\circ}\right)\end{array} & \Delta V / \Delta T & n . v \cdot i \\ 15 & 0 \cdot 61 & 0 \cdot 194 \\ 20 & 0 \cdot 43 & 0 \cdot 287 \\ 25 & 0 \cdot 41 & 0 \cdot 297 \\ 30 & 0 \cdot 36 & 0 \cdot 318 \\ 35 & 0 \cdot 14 & 0 \cdot 434 \\ 40 & -0 \cdot 09 & 0 \cdot 545\end{array}$

Further experimentation would seem to be desirable to establish firmly whether or no there is, as the data suggest, a temperature zone above $35^{\circ}$ within which $\Delta V$ remains approximately constant at about zero. If it exists, its range must be limited, as above a certain point thermal death would occur; indeed, non-viability may perhaps be regarded as thermal death occurring at a temperature at which growth of cell substance is also possible. The upper limit of the zone might be $44^{\circ}$, the temperature indicated above as the maximum for growth under these experimental conditions. It is noteworthy that the results of experiments on the thermal disinfection of similar cultures of Bact. coli are in agreement with $44^{\circ}$ as the minimum temperature at which heat disinfection could occur (Jordan, Jacobs \& Davies, 1947).

The method of calculating the amounts of food used at $35^{\circ}$ in the construction of a new bacterial cell and in its maintenance, employed previously (Jordan \& Jacobs, 1944), cannot be applied at other temperatures as it depended on the constancy of the viable count in the steady phase, and this condition was not fulfilled. There appears to be no ready method of assessing the food used for these purposes. It may be that the amount of food used to form a new cell is substantially the same at all temperatures. If, however, in any conditions the use of the figure of $1.083 \times 10^{-9} \mathrm{mg}$. dehydrated Difco broth per cell as calculated for $35^{\circ}$ (Jordan \& Jacobs, 1944) should lead to an estimate of the food used for new cell formation in excess of the amount actually supplied in any interval, this would indicate that a change in cellular composition or metabolic reactions had occurred. Using this figure, at the largest observed value of $\Delta T$, only

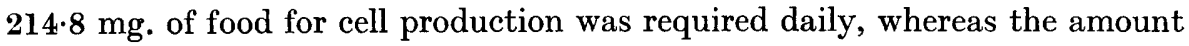


added was $364.8 \mathrm{mg}$. But the amount of $150 \cdot 0 \mathrm{mg}$. apparently available on this basis for maintenance and wastage would have been quite inadequate if the viable cells present were all using food for the latter purposes at the rate of $0.456 \times 10^{-9} \mathrm{mg}$./cell/day calculated for $35^{\circ}$, and the requirement at $15^{\circ}$ must have been considerably smaller than this.

\section{REFERENCES}

BaIL, O. (1929). Ergebnisse experimenteller Populationsforschung. Z. ImmunForsch. 60, 1.

Fisher, R. A. (1938). Statistical Methods for Research Workers, 7th ed. Edinburgh: Oliver and Boyd.

GaLe, E. F. (1940). The production of amines by bacteria. I. The decarboxylation of amino acids by strains of Bacterium coli. Biochem. J. 34, 392.

JoRDAN, R. C. \& JACOBS, S. E. (1944). The growth of bacteria with a constant food supply. I. Preliminary observations on Bact. coli. J. Bact. 48, 579.

Jordan, R. C., Jacobs, S. E. \& Davies, H. E. F.(1947). Studies in the dynamics of disinfection. $\mathrm{X}$. The effect of lethal temperatures on standard cultures of Bact. coli. III. On the variation of the rate of disinfection with temperature at $\mathrm{pH} \mathbf{7 \cdot 0}$, including the calculation of a new and constant temperature coefficient. J. Hyg., Camb. (in the Press).

Lodge, R. M. \& Hinshelwood, C. N. (1943). Physicochemical aspects of bacterial growth. Part IX. The lag phase of Bact. lactis aerogenes. J. Chem. Soc. p. 213.

Penfold, W. J. \& Norris', D. (1912). The relation of concentration of food supply to the generation-time of bacteria. J. Hyg., Camb., 12, 527 .

Sims, A. L. \& Jordan, R. C. (1942). An accurate automatic syringe mechanism. J. Sci. Instrum. 19, 58.

Thompson, D'A. W. (1942). On Grozoth and Form. 2nd ed. Camb. Univ. Press.

WrLson, G. S. \& MrLes, A. A. (1946). Topley \& Wilson's, Principles of Bacteriology and Immunity, 3rd ed. London: Arnold. 